\title{
SOCIOEKONOMICKÁ ÚROVEŇ A FAKTORY KONKURENCESCHOPNOSTI REGIONŮ V ČR
}

\section{SOCIO-ECONOMIC LEVEL AND REGIONAL COMPETITIVENESS} FACTORS OF REGIONS IN THE CZECH REPUBLIC

\section{PROF. RNDR. RENÉ WOKOUN, CSC.}

\author{
ING. NIKOLA KREJČOVÁ \\ \begin{tabular}{l|l} 
Katedra regionálního a lokálního rozvoje & Department of Regional and Local Development
\end{tabular} \\ Fakulta sociálně ekonomická $\quad$ Faculty of Social and Economic Studies \\ Univerzita Jana Evangelisty Purkyně v Ústí n. Labem Jan Evangelista Purkyně University in Ústí n.Labem \\ $\triangle$ Moskevská 54, 40096 Ústí nad Labem, Czech Republic \\ E-mail: rene.wokoun@ujep.cz,nikola.krejcova@ujep.cz
}

\begin{abstract}
Anotace
Regionální konkurenceschopnost je relativně nové, ale v regionální vědě a ekonomické geografii často diskutované téma. Ve vztahu $k$ celkové socioekonomické úrovni územnich celkù je konkurenceschopnost vnimána jako schopnost územnich celků uspět v soutěži s ostatními, př̀ičemž do hodnocení úspěchu je zahrnuta celá rada podstatných aspektù socioekonomické vyspělosti daného regionu. Cílem tohoto přispěvku je zhodnotit konkurenceschopnost regionů České republiky na základě jejich socioekonomické úrovně a indexu konkurenceschopnosti (RCI) a dále identifikovat klícové faktory regionálni konkurenceschopnosti regionu $\check{C} R$. Konkurenceschopnost a socioekonomická úroveň regionů je determinována dostupnými ekonomickými a sociálními indikátory za obdobi 2007-2011. Provedené analýzy prokázaly přetrvávající významné rozdíly $v$ socioekonomické úrovni a konkurenceschopnosti mezi regionem Hl. m. Prahy a zbytkem územi ČR a potvrdily platnost hlavnich faktori̊ konkurenceschopnosti regionů v České republice.
\end{abstract}

\section{Kličová slova}

regionální konkurenceschopnost, faktory regionálni konkurenceschopnosti, socioekonomická úroveñ regionů, HDP, region NUTS II

\section{Anotation}

Regional competitiveness is relatively new but often discussed issue in the field of regional science and economic geography. In relation with the overall socio-economic level of regions, competitiveness is considered as the ability of regions to successfully compete with others and many aspects of the socio-economic performance are taken into account in the evaluation. The aim of this paper is to assess competitiveness of regions in the Czech Republic on the basis of their socio-economic performance and the regional competitiveness index (RCI), and then to identify key factors of competitiveness of regions in the Czech Republic. Both the socio-economic level and regional competitiveness are determined by selected economic and social indicators available for the period of 2007-2011. The analysis showed lasting significant disparities between the capital of Prague and the rest of the country and confirmed validity of the main factors of competitiveness of regions in the Czech Republic.

\section{Key words}

regional competitiveness, factors of regional competitiveness, socio-economic level of regions, GDP, NUTS II region

JEL classification: $R 12$ 


\section{Úvod}

Ekonomický rozvoj je $\mathrm{v}$ tržních ekonomikách jednoznačně spojen s pojmem konkurenceschopnosti jako základního měřítka dlouhodobé úspěšnosti firem a rovněž států a jejich regionů, měst $\mathrm{i}$ obcí. (Wokoun, 2010). Teoretické, metodologické i praktické otázky konkurenceschopnosti ve smyslu konkurenceschopnosti podniků jsou $\mathrm{v}$ ekonomické teorii dobře definované. V př́padě regionální konkurenceschopnosti tomu tak však není. Přitom lze uvést, že v současnosti je regionální dimenze v analýzách a teoretických pracích silně zdůrazňována. Souvisí to s poznáním, že to jsou právě regiony, které jsou základem národní konkurenceschopnosti, nebot' právě na jejich úrovni dochází k přímému střetu mezi tvůrci znalostí a jejich uživateli. Prosperita regionu (F. Corvers, 2003) pak závisí především na tom, jak se podaří danému regionu překonat př́ípadnou propast mezi těmito dvěma skupinami subjektů.

Dalším důvodem, proč je v poslední době kladen větší důraz na regionální úroveň, jsou změny ve světové ekonomice, kdy dochází k její „regionalizaci“ na úrovni nadnárodních uskupení. To vede $\mathrm{k}$ jistému omezení role národních států, které ztrácejí některé možnosti v rámci provádění makroekonomické hospodářské politiky. Je možné deklarovat, že jednotlivé státy jsou stále více vnímány jako regiony v rámci nadnárodních integračních seskupení vzhledem $\mathrm{k}$ charakteru postupů, jimiž ovlivňují některé ekonomické jevy. Tyto postupy se spíše podobají postupům regionálních autorit (M. Beneš, 2006). Podrobnějšś rozbor dostupné literatury o regionální konkurenceschopnosti již byl publikován autory v časopise Regionální studia (R. Wokoun, 2010) a v odborné knize Konkurenceschopnost regionů Evropské unie a České republiky (Wokoun R., Krejčová N., Kouřilová J., Damborský M., Pělucha M., 2012). Další zpracované přehledy literatury obsahují zejména publikace autorů Porter, M. (1990, 1992), Capello, R., Nijkamp, P., et al. (2009), Huggins, R. (2003), Turok, I. (2003), Skokan K. (2004), Viturka M. (2007).

\section{Cíl a metody}

Cílem tohoto př́spěvku je zhodnotit konkurenceschopnost regionů České republiky podle jejich socioekonomické úrovně a indexu konkurenceschopnosti a identifikovat klíčové faktory regionální konkurenceschopnosti regionů České republiky. S ohledem na skutečnost, že projevem konkurenceschopnosti je zejména ekonomická výkonnost při zachování environmentálních a sociálních podmínek, byly autory zvoleny pro analýzu hodnotící projevy konkurenceschopnosti následující ukazatele:

- Hrubý domácí produkt - představuje základní ukazatel ekonomické výkonnosti regionu představující agregovaný ekonomický výkon regionu. Spolu s mírou nezaměstnanosti dokáže dobře ilustrovat ekonomickou situaci regionu.

- Míra nezaměstnanosti - představuje nejpřesnější ekonomický indikátor, který velmi dobře dokresluje aktuální ekonomickou situaci region z důvodu rychlosti, s jakou reaguje na změny v ekonomice.

- Průměrný př́ijem - základní ukazatel sociální úrovně reflektující disponibilní zdroje pro uspokojování základních potřeb a zajištění spotřebitelských standardů. Spolu $\mathrm{s}$ dlouhodobou nezaměstnaností představuje klíčový ukazatel sociální situace.

- Podíl dlouhodobé nezaměstnanosti - ukazatel představující nejhorší formu nezaměstnanosti. Dlouhodobě nezaměstnaní ztrácí pracovní návyky, utíkají mu nové trendy v oboru. Dlouhodobá nezaměstnanost dále přrispívá ke zvýšení kriminality.

- Hrubá přidaná hodnota - důležitý ukazatel přítomnosti odvětví s vyšší přidanou hodnotou $\mathrm{v}$ regionu jako předpoklad současné a budoucí ekonomické prosperity.

- Počet obyvatel regionu - ukazatel rezidenční atraktivnosti regionu.

Regionální konkurenceschopnost regionů ČR je porovnávána s výsledky výzkumného projektu, jehož cílem bylo mimo jiné sestavit žebříček regionů EU podle hodnoty indexu konkurenceschopnosti (RCI) (Wokoun R., Krejčová N., Kouřilová J., Damborský M., Pělucha M., 2012). Výpočet indexu konkurenceschopnosti zahrnoval vybrané ekonomické, sociální a environmentální indikátory za regiony NUTS II v Evropské unii za období 2006-2009. 


\section{Vybrané základní ukazatele pro porovnávání regionální konkurenceschopnosti a socioekonomické úrovně regionů ČR}

Podle hodnoty indexu regionální konkurenceschopnosti (RCI) se regiony ČR umístily s výjimkou Hl. $\mathrm{m}$. Prahy až $\mathrm{v}$ druhé polovině sestaveného evropského žebříčku. Hodnoty RCI a pořadí regionů ČR v rámci evropského srovnání ukazuje Tabulka 1.

Tab. 1: Pořadí regionů ČR podle indexu regionální konkurenceschopnosti

\begin{tabular}{|c|c|c|}
\hline Pořadí v rámci EU & Region & RCI \\
\hline 20 & Praha & $50,45 \%$ \\
\hline 165 & Střední Čechy & $36,27 \%$ \\
\hline 193 & Jihozápad & $32,04 \%$ \\
\hline 226 & Jihovýchod & $28,25 \%$ \\
\hline 228 & Severovýchod & $27,35 \%$ \\
\hline 232 & Střední Morava & $25,65 \%$ \\
\hline 241 & Moravskoslezsko & $23,23 \%$ \\
\hline 245 & Severozápad & $22,70 \%$ \\
\hline
\end{tabular}

Zdroj: (Wokoun R., Krejčová N., Kouřilová J., Damborský M., Pělucha M., 2012)

Z uvedených hodnot RCI je zřejmý výrazný rozdíl mezi Hl. m. Prahou a ostatními regiony ČR. Socioekonomická úroveň většiny regionů je v evropském měřítku srovnatelná s nejslabšími regiony Evropské unie, zejména Polska, Mad’arska, a Rumunska, jak ukazuje Tabulka 2.

Tab. 2: Pořadí regionů EU srovnatelných s regiony $\breve{C} R$

\begin{tabular}{|c|c|c|}
\hline Pořadí v rámci EU & Region & RCI \\
\hline 238 & Slaskie & $23,96 \%$ \\
\hline 239 & Wielkopolskie & $23,72 \%$ \\
\hline 240 & Stredné Slovensko & $23,62 \%$ \\
\hline 241 & Moravskoslezsko & $23,23 \%$ \\
\hline 242 & Lódzkie & $22,96 \%$ \\
\hline 243 & Malopolskie & $22,86 \%$ \\
\hline 244 & Nord-Est & $22,75 \%$ \\
\hline 245 & Severozápad & $22,70 \%$ \\
\hline 246 & Észak-Alföld & $22,64 \%$ \\
\hline 247 & Východné Slovensko & $22,32 \%$ \\
\hline 248 & Sud-Vest Oltenia & $22,24 \%$ \\
\hline 249 & Dolnoslaskie & $22,20 \%$ \\
\hline
\end{tabular}

Základním ukazatelem pro hodnocení socioekonomické úrovně regionů je hrubý domácí produkt, který představuje hodnotu statků a služeb, jež byly v daném regionu vyprodukovány. 
Tab. 3: Vývoj regionálního HDP b.c. (NUTS II), rok 2000=100\%

\begin{tabular}{|l|r|r|r|r|r|c|}
\hline NUTS II & $\mathbf{2 0 0 7}$ & $\mathbf{2 0 0 8}$ & $\mathbf{2 0 0 9}$ & $\mathbf{2 0 1 0}$ & $\mathbf{2 0 1 1}$ & $\begin{array}{l}\text { Průměrné tempo růstu } \\
\text { HDP }\end{array}$ \\
\hline Praha & 177,61 & 190,92 & 185,54 & 190,86 & 190,13 & 1,06 \\
\hline Střední Čechy & 166,71 & 176,33 & 169,05 & 169,59 & 174,54 & 1,05 \\
\hline Jihozápad & 155,47 & 154,34 & 153,77 & 156,17 & 157,80 & 1,04 \\
\hline Severozápad & 150,67 & 156,27 & 158,66 & 154,78 & 153,00 & 1,04 \\
\hline Severovýchod & 146,33 & 150,54 & 147,62 & 149,73 & 151,07 & 1,04 \\
\hline Jihovýchod & 159,38 & 167,87 & 165,38 & 164,93 & 167,89 & 1,05 \\
\hline Střední Morava & 151,41 & 162,03 & 159,24 & 158,69 & 161,68 & 1,04 \\
\hline Moravskoslezsko & 167,98 & 177,92 & 166,49 & 171,37 & 177,38 & 1,05 \\
\hline ČR & $\mathbf{1 6 1 , 3 7}$ & $\mathbf{1 6 9 , 5 6}$ & $\mathbf{1 6 5 , 6 2}$ & $\mathbf{1 6 7 , 4 0}$ & $\mathbf{1 6 9 , 2 5}$ & $\mathbf{1 , 0 5}$ \\
\hline
\end{tabular}

Legenda:

\begin{tabular}{|l|l|l|}
\hline nad průměrem ČR & \multirow{3}{*}{ srovnatelné s ČR } \\
\cline { 1 - 2 } výrazně nad průměrem ČR & výrazně pod průměrem ČR & \\
\hline
\end{tabular}

Zdroj: (Wokoun R., Krejčová N., Kouřilová J., Damborský M., Pělucha M., 2012)

Na základě hodnot kumulované změny HDP regionů NUTS II uvedených v Tabulce 3 je možné konstatovat, že z hlediska vývoje socioekonomické úrovně existují čtyři základní kategorie regionů:

\section{Praha}

Hlavní město vykazuje dlouhodobě nejvyšší hodnoty HDP a svou ekonomickou výkoností ve sledovaném období vysoko přesahuje průměr ČR. Metropolitní charakter investičně velmi atraktivního regionu s výrazně odlišnou strukturou ekonomiky umožňuje výraznou akceleraci růstu. Přestože průměrné tempo růstu HDP v první polovině sledované dekády bylo vyšší než ve druhé polovině, své dominantní postavení si Praha stále uchovává a tento trend bude pravděpodobně i nadále pokračovat.

Tab. 4: Průměrné tempo růstu HDP v Praze

\begin{tabular}{|c|c|}
\hline \multicolumn{2}{|c|}{ Průměrné tempo růstu HDP v Praze } \\
\hline $2001-2006$ & 1,08 \\
\hline $2007-2011$ & 1,04 \\
\hline & Zdroj: (Wokoun R., Krejčová N., Kouřilová J., Damborský M., Pělucha M., 2012)
\end{tabular}

Socioekonomická úroveň regionu hlavního města vzhledem k ostatním regionům ČR zcela odpovídá jeho konkurenceschopnosti podle RCI.

\section{Regiony, jejichž př́růstek HDP významně překračuje přírůstek ČR}

V rámci úrovně NUTS II do této skupiny patř́i regiony Střední Čechy a Moravskoslezsko. Druhé pořadí Středních Čech nepřináší žádné výrazné překvapení vzhledem $\mathrm{k}$ poloze regionu v bezprostřední blízkosti hlavního města, jeho investiční i rezidenční atraktivnosti a dobrému dopravnímu napojení na ostatní regiony. Vývoj Středních Čech je pozitivně ovlivňován výrazným rozvojem Prahy zejména proto, že Praha nemá větší rezervy vhodného území pro další extenzivní expanzi a existují zde rozdíly v ceně práce a pozemků mezi Prahou a Středními Čechami. Určité zlepšení infrastruktury v okolí Prahy může mít vliv na dekoncentraci investic a kapitálu. Středočeský region, jehož výkonnost byla dříve dlouhodobě negativně ovlivňována právě Prahou, dnes naopak z dynamiky Prahy profituje. Ve sledovaném období 2000-2011 byl průměrný přírůstek HDP v těsném závěsu za Prahou. 
Socioekonomické postavení regionu odpovídá jeho konkurenceschopnosti v rámci České republiky, nicméně míra jeho „Zaostávání“ za Prahou je v obou př́padech poměrně vysoká. V evropském porovnání konkurenceschopnosti je tato skutečnost ještě patrnější vzhledem k zařazení regionu do slabší poloviny žebříčku RCI.

Analýza regionu Moravskoslezsko přinesla určitá pozoruhodná zjištění. Zatímco $\mathrm{v}$ žebříčku konkurenceschopnosti výrazně zaostává (umístil se na jednom z posledních míst v rámci Č́R i celé EU), kumulovaná změna jeho ekonomické výkonnosti vzhledem k r. 2000, s výjimkou jednoho roku v rámci období 2007-2011, je vyšší než ve Středních Čechách. Tabulka 5 ukazuje na možnou př́íčinu této skutečnosti - př́liv př́mých zahraničních investic. Druhou možnou příčinou je vysoká míra čerpání prostředků ze strukturálních fondů EU během sledovaného období. Průměrné tempo růstu HDP v období 2000-2011 je v obou regionech přibližně stejné.

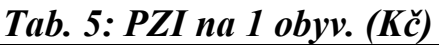

\begin{tabular}{|c|c|}
\hline Region NUTS II & PZI \\
\hline Praha & 1002383 \\
\hline Střední Čechy & 196976 \\
\hline Moravskoslezsko & 134326 \\
\hline Jihozápad & 131835 \\
\hline Jihovýchod & 125227 \\
\hline Severovýchod & 110804 \\
\hline Severozápad & 109546 \\
\hline Střední Morava & 64171 \\
\hline ČR & $\mathbf{2 2 9 ~ 1 0 8}$ \\
\hline
\end{tabular}

\section{Regiony, jejichž př́růstek HDP je srovnatelný s přírůstkem ČR}

Na základě výsledků uvedených v Tabulce 3 do této kategorie spadá region NUTS II Jihovýchod a také Střední Morava. Je patrné, že toto relativně př́iznivé umístění regionu Jihovýchod, jak v případě konkurenceschopnosti, tak v prrípadě př́růstku HDP ve vztahu k ČR, je do značné míry způsobeno př́tomností druhého nejsilnějšího ekonomického centra $\mathrm{v} \breve{C} \mathrm{R}-$ města Brna. Pokud jde o konkurenceschopnost regionu, je pozoruhodné jeho umístění v žebříčku podle RCI až za regionem Jihozápad, který vykazuje podstatně nižší přírůstky HDP ve vztahu k ČR. Tuto skutečnost je možné zdůvodnit značnými vnitřními disparitami v obou regionech. V př́padě regionu NUTS II Jihovýchod se jedná především o ekonomicky výkonné město Brno (včetně celé své aglomerace a některých dalších měst, především Jihlavy) a zaostávající regiony na Vysočině a podél hranic s Rakouskem a Slovenskem na straně druhé. Region NUTS II Jihozápad je možné rozdělit na ekonomicky slabý Jihočeský kraj a výkonnější Plzeňský kraj, jak vyplývá z Tabulky 6.

Region NUTS II Střední Morava celkově nepatřil v období 2007-2011 k výkonnostně nejslabším, avšak i zde je třeba si uvědomit značné vnitřní disparity dané relativně výkonnějšími městy Zlín (zlínská aglomerace) a Olomouc a zbytkem regionu. Zlínský kraj je spíše podprůměrně růstový, v letech 2008 a 2009 byly přirůstky jeho HDP na celorepublikové úrovni, Olomoucký kraj ale patří mezi ekonomicky nejslabší regiony. Podle indexu konkurenceschopnosti se oba NUTS II regiony umístily na posledních místech evropského žebřičku a na prostředních místech v rámci českých regionů. 
Tab. 6: Vývoj regionálního HDP b.c. (NUTS III), rok 2000=100\%

\begin{tabular}{|l|r|r|r|r|r|}
\hline Region NUTS III & $\mathbf{2 0 0 7}$ & $\mathbf{2 0 0 8}$ & $\mathbf{2 0 0 9}$ & $\mathbf{2 0 1 0}$ & $\mathbf{2 0 1 1}$ \\
\hline Hlavní město Praha & 177,6 & 190,9 & 185,5 & 190,9 & 190,1 \\
\hline Středočeský kraj & 166,7 & 176,3 & 169,0 & 169,6 & 174,5 \\
\hline Jihočeský kraj & 150,3 & 151,8 & 151,8 & 151,9 & 152,3 \\
\hline Plzeňský kraj & 161,4 & 157,2 & 156,0 & 161,0 & 164,0 \\
\hline Karlovarský kraj & 136,9 & 138,8 & 139,5 & 136,4 & 134,1 \\
\hline Ústecký kraj & 156,0 & 163,0 & 166,1 & 161,9 & 160,4 \\
\hline Liberecký kraj & 138,5 & 141,0 & 137,1 & 140,6 & 142,9 \\
\hline Královéhradecký kraj & 143,6 & 150,0 & 149,2 & 151,2 & 151,0 \\
\hline Pardubický kraj & 156,5 & 159,6 & 155,0 & 156,1 & 158,4 \\
\hline Vysočina & 158,8 & 158,6 & 158,0 & 156,4 & 160,0 \\
\hline Jihomoravský kraj & 159,6 & 171,7 & 168,5 & 168,5 & 171,2 \\
\hline Olomoucký kraj & 149,0 & 156,7 & 154,0 & 156,3 & 158,6 \\
\hline Zlínský kraj & 153,8 & 167,4 & 164,6 & 161,2 & 164,9 \\
\hline Moravskoslezský kraj & 168,0 & 177,9 & 166,5 & 171,4 & 177,4 \\
\hline Česká republika & $\mathbf{1 6 1 , 4}$ & $\mathbf{1 6 9 , 6}$ & $\mathbf{1 6 5 , 6}$ & $\mathbf{1 6 7 , 4}$ & $\mathbf{1 6 9 , 2}$ \\
\hline
\end{tabular}

Legenda:

\begin{tabular}{|l|l|l|}
\hline nad průměrem ČR & pod průměrem ČR & \multirow{3}{*}{ srovnatelné s ČR } \\
\cline { 1 - 2 } výrazně nad průměrem ČR & výrazně pod průměrem ČR & \\
\hline
\end{tabular}

Zdroj: (Wokoun R., Krejčová N., Kouřilová J., Damborský M., Pělucha M., 2012)

Po provedení analýzy indikátoru regionů na úrovni NUTS III bylo nutné rozlišit v rámci této kategorie dvě skupiny regionů: a) Jihomoravský kraj jako mírně nadprůměrně růstový, resp. srovnatelný s celorepublikovým trendem a b) Vysočina, Zlínský, Plzeňský a Ústecký kraj jako regiony stagnující, resp. mírně podprůměrně růstové. Je zřejmé, že s výjimkou kraje Vysočina v letech 2008 a 2010 a Plzeňského kraje v roce 2008 se tyto kraje pravděpodobně ve sledovaném období relativně úspěšně vyrovnávaly s dopady transformace $\mathrm{v}$ porovnání s jinými regiony, především některými pohraničními. Ústecký kraj představuje v tomto smyslu určité př́ijemné překvapení vzhledem $\mathrm{k}$ tomu, že jako jeden ze strukturálně nejvíce zasažený region vykazoval jen mírně podprůměrnou výkonnost a absolutní hodnoty jeho HDP v mezikrajském srovnání nepatřily zdaleka k nejhorším. V roce 2009 se přírůstek HDP dokonce pohyboval nad celorepublikovou úrovní.

\section{Regiony, jejichž př́růstek je významně pod průměrem ČR}

Na základě údajů uvedených v Tabulce 3 je možné konstatovat, že do této poslední kategorie patř́ tři regiony NUTS II: Jihozápad, Severozápad a Severovýchod, zahrnující celkem 7 krajů. Region Jihozápad se podle hodnoty indexu konkurenceschopnosti umístil mezi prvními třemi českými regiony, především zásluhou Plzeňského kraje, jak je patrné z Tabulky 6. Jihočeskému kraji je možné naopak přičíst nízké hodnoty ekonomické výkonnosti s přihlédnutím k celorepublikovým hodnotám. Tento nepoměr v umístění pravděpodobně znamená, že ve srovnání s jinými NUTS II regiony dokáže Jihozápad jako celek, i přes nízkou ekonomickou výkonnost, využít svůj celkový vnitřní potenciál lépe než jiné regiony, zejména Moravskoslezsko, Jihovýchod nebo Střední Morava, které naopak vykazují intenzivnější ekonomický růst. Region Severozápad se podle RCI umístil na poslední prííčce v rámci ČR. Slabá konkurenceschopnost regionu je negativně ovlivněna celkově slabým ekonomickým růstem a dalšími faktory, které jsou podrobněji popsány v dalších kapitolách. Oba kraje, Ústecký a Karlovarský, procházejí vleklou a nepř́iliš úspěšnou sociální a ekonomickou restrukturalizací, která může přerůst až v dlouhodobou stagnaci celého region NUTS II Severozápad. Jejich míra nezaměstnanosti vysoce překračuje celorepublikový průměr. V uvedených krajích se koncentrují strukturálně postižené regiony (okresy) a značná část hospodářsky slabých regionů ČR. 
Poslední dostupná data však naznačují možnou akceleraci růstu i v těchto regionech, zejména v kraji Ústeckém, jak ukazuje Tabulka 6. Jednoznačně nejhorší, z hlediska růstu ekonomické výkonnosti, je region Severovýchod. Všechny tři kraje tvořící tento region vykazují nízké tempo růstu v období 2000-2011. Poněkud překvapivě nejnižší hodnoty hluboko pod celorepublikovou úrovní byly zjištěny u Libereckého kraje. Spolu s Karlovarským krajem tvoří skupinu dvou výkonnostně nejslabších krajů ČR.

Tab. 7: HDP/obyv. (2006-2010). $\check{C} R=100 \%$

\begin{tabular}{|c|c|c|c|c|c|}
\hline & $\mathbf{2 0 0 6}$ & $\mathbf{2 0 0 7}$ & $\mathbf{2 0 0 8}$ & $\mathbf{2 0 0 9}$ & $\mathbf{2 0 1 0}$ \\
\hline ČR & $\mathbf{1 0 0}$ & $\mathbf{1 0 0}$ & $\mathbf{1 0 0}$ & $\mathbf{1 0 0}$ & $\mathbf{1 0 0}$ \\
\hline Praha & 210,4 & 214,1 & 216,1 & 213,2 & 216,0 \\
\hline Střední Čechy & 93,8 & 93,2 & 92,5 & 89,6 & 87,9 \\
\hline Jihozápad & 92,6 & 89,4 & 84,5 & 86,1 & 86,6 \\
\hline Severozápad & 79,9 & 78,8 & 77,8 & 81,2 & 78,7 \\
\hline Severovýchod & 83,4 & 82,4 & 80,9 & 81,4 & 81,8 \\
\hline Jihovýchod & 88,7 & 89,3 & 89,9 & 90,8 & 89,7 \\
\hline Střední Morava & 77,4 & 77,5 & 79,6 & 80,5 & 79,7 \\
\hline Moravskoslezsko & 83,2 & 83,8 & 85,3 & 82,2 & 84,3 \\
\hline
\end{tabular}

Legenda:

nejhorší

nejlepší

Dalším vhodným souhrnným ukazatelem pro porovnávání regionální konkurenceschopnosti a socioekonomické úrovně regionů je HDP/obyvatele. Tabulka 7 umožňuje srovnání podílů vytvořeného HDP na 1 obyvatele $\mathrm{v}$ jednotlivých regionech NUTS II oproti celorepublikovému průměru. Celkově je možno říci, že poměry jednotlivých regionů vůči celorepublikovému průměru jsou relativně dlouhodobě stabilní, přesto lze zjistit určité trendy, které ve svém důsledku ústí do změn postavení některých regionů, zejména v porovnání s ukazatelem přírůstku HDP. Lze konstatovat, že nejnižší úroveň HDP/obyvatele se ukazuje v regionu Střední Morava a Severozápad, naopak nejvyšší je v Praze. Druhé pořadí náleží Středním Čechám. Zbytek regionů ČR vykazuje vzájemně podobné hodnoty pohybující se hlouběji pod průměrem ČR. V porovnání s pořadím regionů dle IRK je možné pozorovat překvapující výsledky v regionech Moravskoslezsko a Severozápad, které vykazovaly nejnižší hodnoty indexu konkurenceschopnosti, avšak jejich průměrná výše HDP na obyvatele není v porovnání s ostatními regiony ČR nejhorší. Oproti tomu regiony Severovýchod a Střední Morava, které byly v rámci ČR spiśše průměrné v žebříčku RCI, jsou v tomto případě umístěny jako poslední.

Tab. 8: Průměrné HDP/obyvatele (2006-2010)

\begin{tabular}{|c|c|}
\hline Region & Průměr HDP/obyv. $\mathbf{( 2 0 0 6 - 2 0 1 0 )}$ ČR=100\% \\
\hline Praha & 214,0 \\
\hline ČR & 100,0 \\
\hline Střední Čechy & 91,4 \\
\hline Jihovýchod & 89,7 \\
\hline Jihozápad & 87,8 \\
\hline Moravskoslezsko & 83,7 \\
\hline Severozápad & 82,0 \\
\hline Severovýchod & 79,3 \\
\hline Střední Morava & 78,9 \\
\hline
\end{tabular}


Ekonomická struktura regionu s vyšším podílem odvětví s vysokou přidanou hodnotou je předpokladem pro zvyšování jeho celkové socioekonomické úrovně. Př́tomnost takových odvětví je podmíněna dostatečně kvalifikovanou pracovní silou s odborným vzděláním odpovídajícím poptávce na trhu práce. Grafy 1 a 2 ukazují přítomnost takových odvětví v hlavním městě Praha v poměru, který je nesrovnatelný s ostatními regiony.

\section{Graf 1: Vývoj hrubé přidané hodnoty v mil. Ǩ̌ - NUTS II}

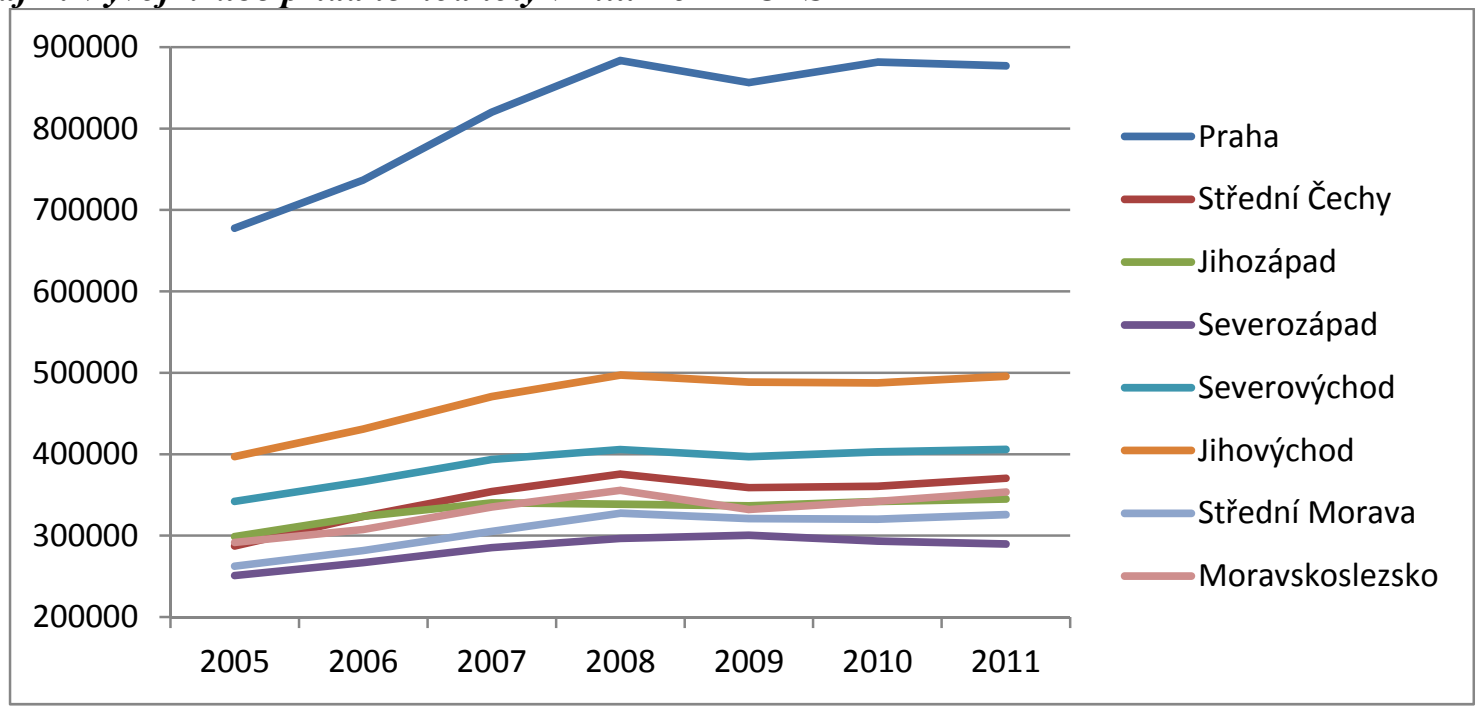

Graf 2: Vývoj hrubé přidané hodnoty v mil. Ǩ̌ - NUTS III

Zdroj: ČSÚ, 2012

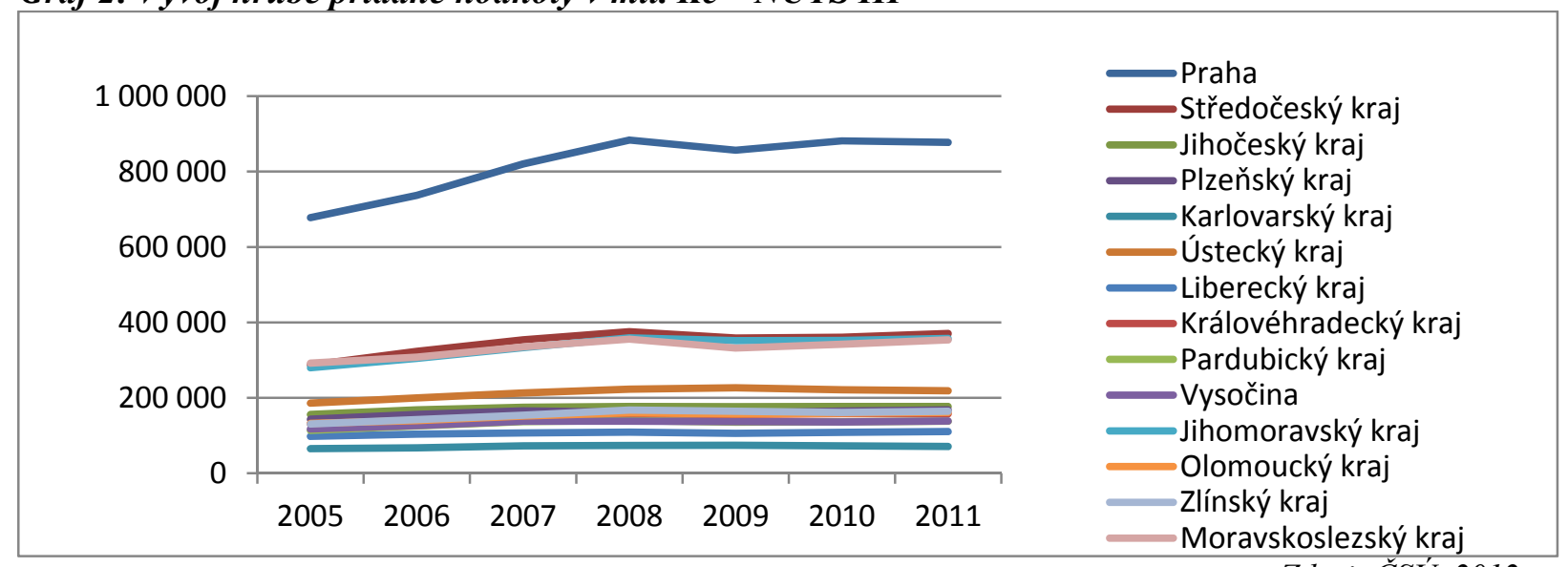

Zdroj: ČSÚ, 2012

O druhé místo se dělí Jihovýchod a Střední Čechy, tedy regiony, kde se lokalizují, podobně jako v př́padě Prahy, významné instituce, sídla nebo velké pobočky velkých firem, jejichž ekonomická činnost je zaměřena na progresivní odvětví, výzkum a služby vyššího řádu. V rámci mezikrajského porovnání nelze pominout umístění Moravskoslezského kraje na jednom z předních míst.

Životní úroveň jejich obyvatel regionů lze měřit různými ukazateli. Jedním z nejvhodnějších je ukazatel disponibilního př́ijmu v přepočtu na 1 obyvatele. 
Graf 3: Disponibilní př́jem domácností na 1 obyvatele v regionech NUTS II (PPS)

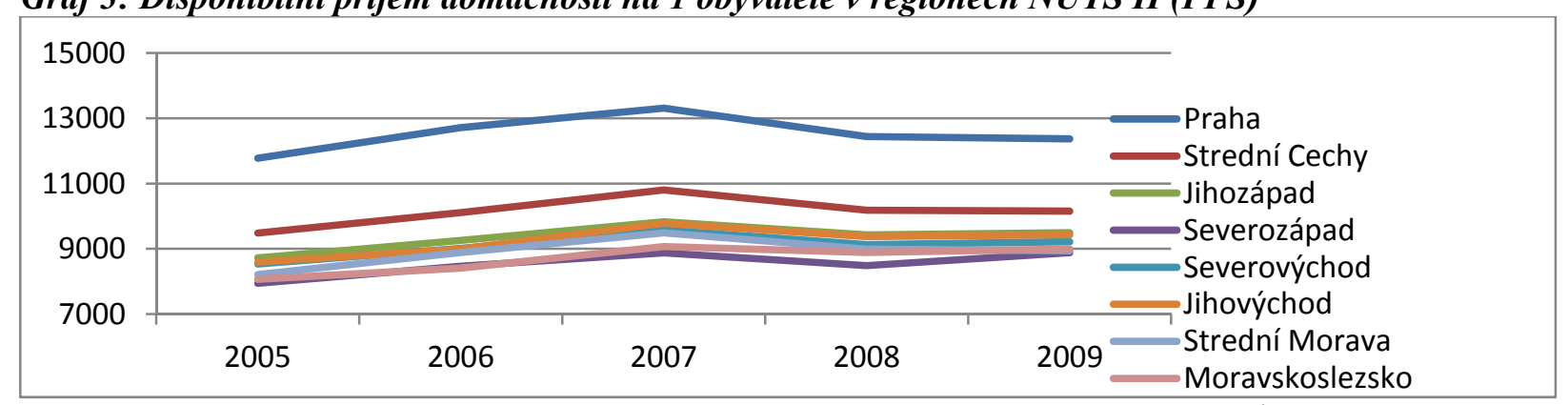

Zdroj: Eurostat, 2012

Výše disponibilního př́ijmu $\mathrm{v}$ regionech je ovlivněna strukturou zaměstnanosti, podnikatelských subjektů, mírou nezaměstnanosti a kvalifikací pracovní síly. Nezanedbatelný vliv na tento ukazatel mají i regionální rozdíly v cenové hladině, nebot’ modifikují reálnou výši důchodu. Jak ukazuje Graf 3, ukazatel disponibilního př́ijmu domácností na jednoho obyvatele nejlépe reflektuje pořadí regionů NUTS II v žebříčku sestaveného podle hodnot RCI. Je vidět tradičně dominantní pozici Prahy následované Středními Čechami a zbytek regionů ČR, z nichž nejnižší hodnoty vykazují regiony Severozápad a Moravskoslezsko.

Graf 4: Podíl dlouhodobé nezaměstnanosti v regionech NUTS II (\% celkové nezaměstnanosti)

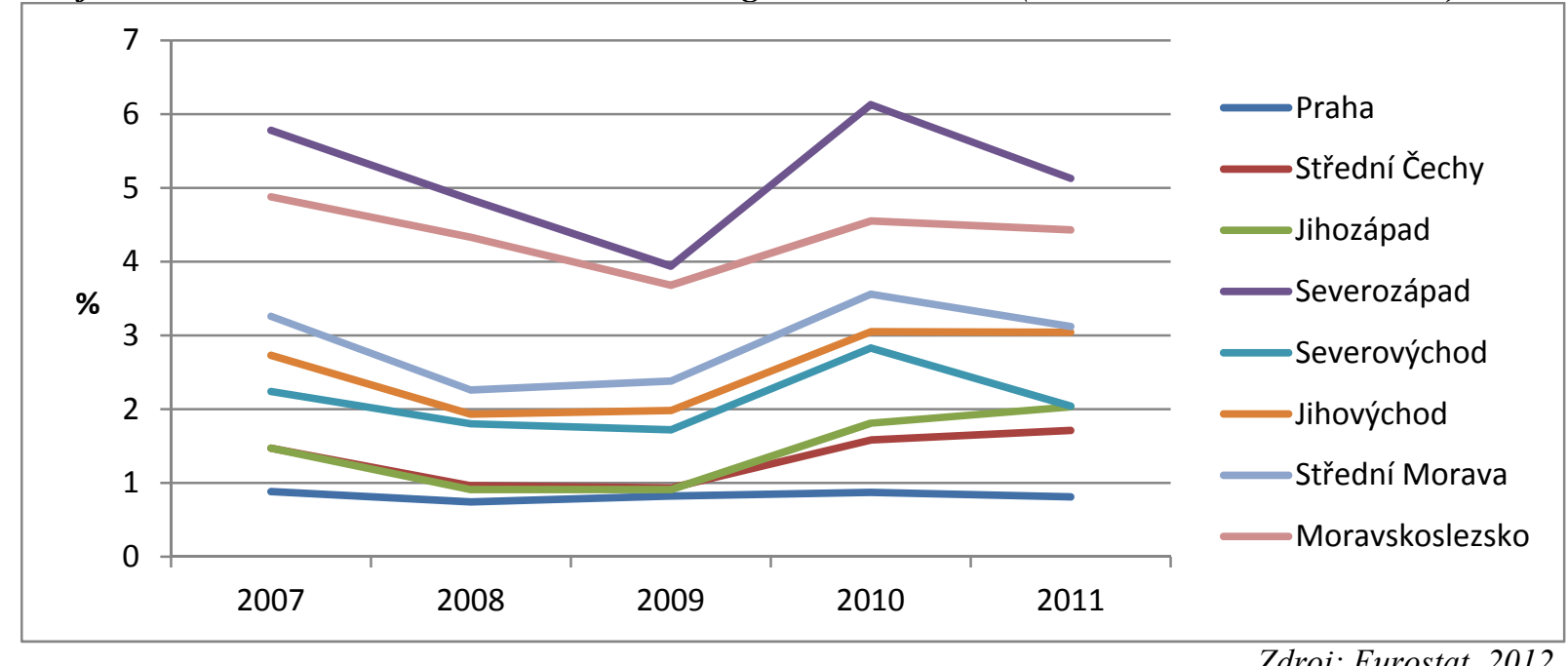


Graf 5: Vývoj počtu obyvatel v regionech NUTS II v období 2000-2011

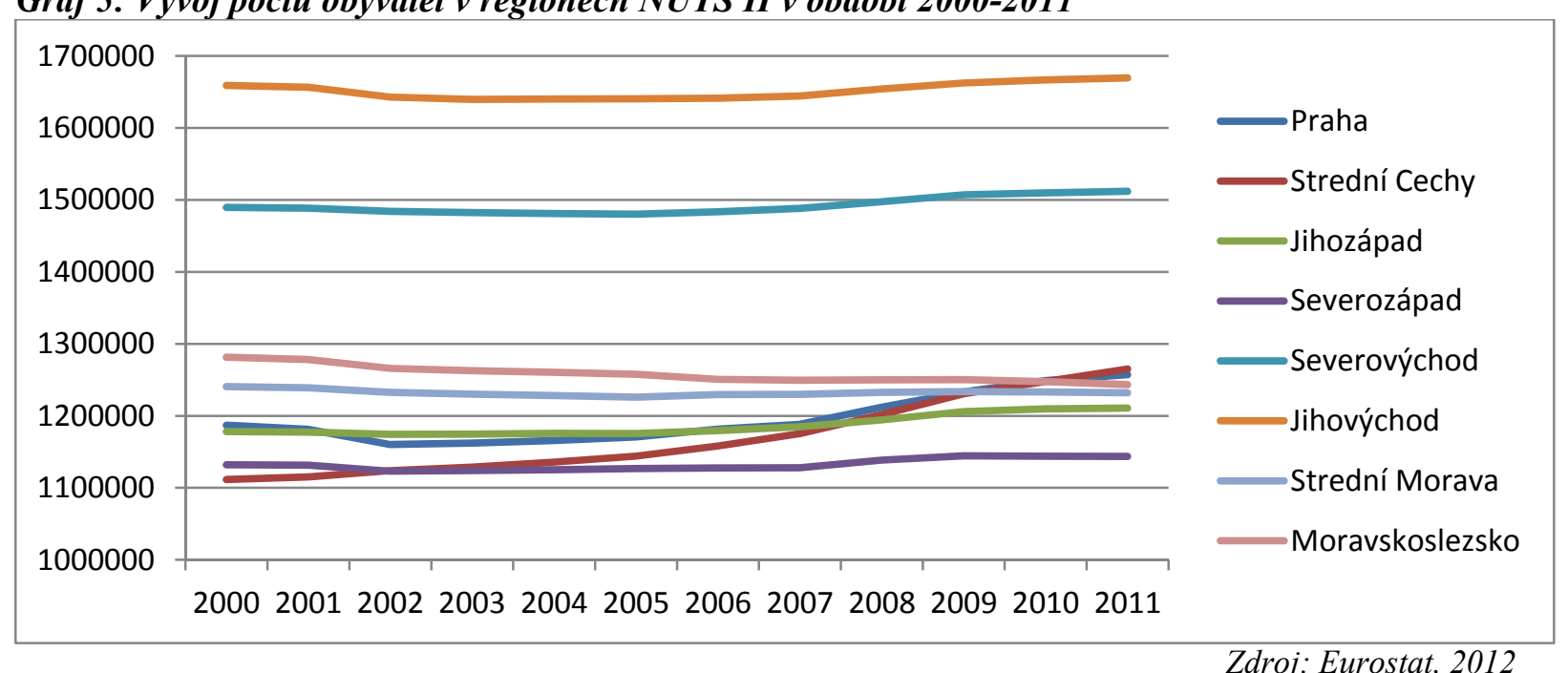

Socioekonomický vývoj v jednotlivých regionech NUTS II se promítá také do vývoje velikosti regionální populace. Jak ukazuje Graf 5, výrazně populačně rostoucí jsou regiony Praha a Střední Čechy, zřetelnou klesající tendenci je možné pozorovat v regionu Moravskoslezsko, mírně klesající v regionu Střední Morava a Severozápad. K odlivu obyvatelstva v těchto regionech dochází především v důsledku nedostatku pracovních příležitostí, který se promítá do míry nezaměstnanosti, především dlouhodobé. Graf 4 ukazuje vysokou dlouhodobou nezaměstnanost především v regionu Severozápad, přestože v posledních dvou letech dochází $\mathrm{k}$ jejímu výraznému snižování, dále v regionech Moravskoslezsko a Střední Morava. Ostatní regiony jsou z tohoto hlediska spíše stagnující.

\section{Hlavní faktory a vývojové trendy regionální konkurenceschopnosti ČR}

Z porovnání hlavních faktorů regionální konkurenceschopnosti a regionálního rozvoje je zřejmé určité tendence, které lze charakterizovat následujícím způsobem:

- přetrvávají poměrně významné rozdíly v socioekonomické úrovni hlavního města Prahy a ostatních regionů v ČR v řadě ukazatelů, jako je především celková konkurenceschopnost měřená pomocí IRK, HDP/obyv., HDP, hrubá přidaná hodnota, disponibilní př́ijem domácností na obyvatele a velikost populace. Na druhé straně však, zejména v období globální ekonomické recese, dochází $\mathrm{k}$ určité slabé konvergenci v rámci všech regionů NUTS II v ukazateli disponibilního prŕjimu, který významně poklesl v Praze a Středních Čechách a naopak vzrostl v regionu Severozápad, jehož hodnota byla na počátku zkoumaného období (2005) od pražské hodnoty nejvíce vzdálená.

- v regionech postižených nezbytností rozsáhlé restrukturalizace průmyslu (zejména v regionu Severozápad a Moravskoslezsko) je stále vysoká dlouhodobá nezaměstnanost, nedaří se dostatečně rychle efektivně realizovat potřebné strukturální přeměny;

- prohlubuje se odlišnost venkovského prostředí komparativně nevýhodně vůči prostředí městskému, příčinou mohou být nepříznivé podmínky pro podnikání zejména $\mathrm{v}$ malých obcích, kde dochází ke stárnutí venkovského obyvatelstva a vylidňování;

- zaostává ekonomická úroveň př́hraničních okresů ležících na severovýchodních hranicích České republiky;

- přetrvává nízký zájem investorů o region severovýchodní Moravy a Slezska, což brání ekonomickému rozvoji v tomto regionu;

- existují rozdíly mezi podílem vysokoškolsky vzdělaných lidí ve dvou největších městech (Praha a Brno) a zbytkem území ČR;

- projevuje se stále narušené životní prostředí v důsledku minulé průmyslové činnosti $\mathrm{v}$ severozápadních Čechách a na severní Moravě a v důsledku rozvoje automobilové dopravy v Praze a dalších velkých městech. 
Z výše uvedených vývojových trendů lze odvodit klíčové faktory konkurenceschopnosti regionů ČR:

- př́rodní podmínky jako dlouhodobé determinanty regionálního rozvoje,

- hmotné faktory v podobě jejich produkčního potenciálu a infrastruktury,

- nehmotné faktory zejména inovace a schopnost jejich vytváření a šíření, dostupnost a účinné využití informační a komunikační technologie (ICT), ekologická udržitelnost rozvoje, institucionální prostředí,

- lidské zdroje s př́slušnou úrovní dovedností v rámci odborného vzdělání

\section{Závěr}

Jednou z opravdu silných stránek regionálního rozvoje ČR je kvalifikovaná a i nadále relativně levná pracovní síla. Zároveň se však postupně ukazuje, že v některých částech jednotlivých regionů NUTS II se $\mathrm{v}$ důsledku rozvoje nových podnikatelských aktivit spojených $\mathrm{s}$ př́livem prímých zahraničních investic začíná nedostávat určitých typů pracovních sil (podle kvalifikace), což je negativní tendence jako z aspektu konkurenceschopnosti, tak obecně regionálního rozvoje. K dalším hlavním faktorům růstu konkurenceschopnosti regionů lze zařadit právě již naznačený rozvoj výrobních kapacit spojených s realizací př́mých zahraničních investic, což souvisí s reálně existující širokou nabídkou ploch pro rozvoj podnikání $\mathrm{v}$ jednotlivých regionech. Tento rozvoj vytváŕí předpoklady pro vznik nových vazeb s tuzemskými podnikatelskými subjekty a jejich potenciální budoucí prosazení se na zahraničních trzích. I zde lze identifikovat jednu z příčin dynamického rozvoje sektoru malého a středního podnikání v České republice.

V oblasti slabých stránek lze identifikovat především ty slabé stránky, které svým charakterem i nadále brzdí rozvoj podnikatelských aktivit, např. komplikace spojené se samotným zahájením podnikatelských aktivit. Další slabé stránky jsou spojené s nedostatky v různých oblastech infrastruktury, např. dopravní či komunikační. Dále jsou to slabé stránky spojené s fungováním trhu práce, např̀. nízká mobilita pracovní síly, problémy s bydlením apod. Specifický problém představuje celkově nízká úroveň podpory rozvoje vědy a výzkumu, spolupráce výzkumných institucí a podnikatelských subjektů a znalostní ekonomiky obecně, což negativně ovlivňuje konkurenceschopnost regionů zejména v globalizujícím se světě.

\section{Literatura}

[1] BENEŠ, M. Konkurenceschopnost a konkurenční výhoda [Working Paper č. 5]. Brno> CVKS ESF MU, 2006.

[2] CAPELLO, R., NIJKAMP, P., et al. Handbook of Regional Growth and Development Theories, Cheltenham: Edward Elgar Publishing Limited, 2009. 542 p.

[3] CORVERS, F. Indicators for Regional Innovation Performance. In International Conference on Entrepreneurship and Business Incubation „Strengthening the Regional Innovation Profile“, Bremen, 16-17 October 2003. Dostupné z: <http:// www.cisv.org>.

[4] HUGGINS, R. Creating a UK Competitiveness index: Regional and local benchmarking. Regional Studies, 2003, Vol. 37, 89 - 96, 2003.

[5] PORTER M. E. Competitive advantage: Creating and Sustaining Superior Performance, Issue 10 PA, Consulting Group London, 1992.

[6] PORTER, M. The Competitive Advantage of Nations. New York: The Free Press, 1990.

[7] SKOKAN K. Konkurenceschopnost, inovace a klastry v regionálním rozvoji. Ostrava: Repronis, 2004. 160 s. ISBN 80-7329-059-6.

[8] STORPER, M. The Regional World: Territorial Development in a Global Economy. New York: Guilford, 1997.

[9] TUROK, I. Cities, Regions and Competitiveness. Regional Studies, 2003, Vol.38, No.9, pp. 1069 $-1083$.

[10] VITURKA M. Konkurenceschopnost regionů, možnosti jejího hodnocení a stimulace. In Klímová, V. (ed). X. mezinárodni kolokvium o regionálnich vědách. Sborník přispěvků. Brno: Masarykova univerzita, 2007. pp. 44-55. ISBN 978-80-210-4325-1. 
[11] WOKOUN, R. Regional Competitiveness and Regional Development Factors in the Czech Republic. In Buček, M., Capello, R., Hudec, O., Nijkamp, P. (eds.). 3rd Central European Conference in Regional Science [CD-ROM]. Košice, 2009. pp. 898-905. ISBN 978-80-5530329-1.

[12] WOKOUN R. Teoretické a metodologické př́stupy k výzkumu regionální konkurenceschopnosti. Regionálni studia, číslo 2/2010, Vysoká škola ekonomická v Praze, s. 27. ISSN 1803-1471.

[13] WOKOUN R., KREJČOVÁ N., KOUŘILOVÁ J., DAMBORSKÝ M., PĚLUCHA M. Konkurenceschopnost regionı̊ Evropské unie a České republiky. Univerzita Jana Evangelisty Purkyně v Ústí nad Labem, 2012. 126 s. ISBN 978-80-7414-534-6.

Př́spěvek byl zpracován v rámci grantu GA ČR 402/09/0179 „Konkurenceschopnost regionů v rámci ČR a EU“, financovaného Grantovou agenturou České republiky. 